Status Report 2016-2019

\title{
Deep and Shallow Seismic Studies: Results
}

\author{
WILLIAM K MOHANTY* and BHAGYASHREE SAHOO \\ Department of Geology and Geophysics, Indian Institute of Technology, Kharagpur West Bengal 721 \\ 302
}

(Received on 29 August 2019; Accepted on 29 September 2019)

An approach to the study on the behaviour of Earth's shallow level crustal segments as well as in its deeper level become essential in understanding the changes taking place as the consequences of natural as well as the human intervenes. Whether it is for seismic hazard assessment or as a proxy of underlying natural resources, India has the same pace as its counterparts in the world. Predicting the disasters due to diastrophic processes, understanding the crustal structures, profiling the subsurface, Imaging out underlying strata configurations, the natural resources, etc. become the prime interest for researchers in the country.

Shallow seismic techniques include reflection, refraction, borehole and surface wave methods. Application of this technique include examining sedimentology and stratigraphy, detecting subsurface geologic structures, mapping the top of bedrock, etc. it is also used to delineate geological and geotechnical features up to certain depth. This method is used in engineering, environmental and groundwater-related investigations. Application in hydrogeology includes mapping hydrogeological features, assessing hydrological characteristics, measuring the depth to the water table, delineating the interface between the saturated and unsaturated layers etc. Shallow seismic surveys provide precise information on the location of active faults and their geometry which is useful for engineering and construction work. Deep seismic reflection studies have great application in exploration techniques to study the crust and upper mantle. This technique can explain subsurface discontinuities, layering, and probable rock structures which are suitable for the investigation of coal, oil, gas, groundwater and massive metallic deposits.
Among the recent investigations on this aspect, $3 \mathrm{D}$ seismic velocity structures in the northeast India region and its adjoining areas to understand the geodynamic processes of the Indian lithosphere is vital on the seismic hazard point of view. Similarly, research on the conformation of Wharton Basin in the Indian Ocean as one of the most active intra-plate deformation zones was after the occurrence of the 2012 great earthquakes ( $\mathrm{Mw} \geq 8.2$ ) (Raoof et al., 2017) has been done. Microtremor analysis is of great importance for figuring out the liquefaction potential, surface geology characterisation, which had been carried out in the Kachchh region of western India. Researchers do also keep interested in understanding the uplift and magmatic underplating beneath the crust of Deccan provinces by using the ratio of seismic wave velocities. In context to the petroliferous basin, their place of hydrocarbons like porosity is mapped from seismic inversion in gas hydrate-bearing sediments in seismic sections of Mahanadi and $\mathrm{K}-\mathrm{G}$ basin (Kumar et al., 2016).

Studies include the tectonics implications in Southern India. One of the important ones is the Cuddapah basin and its eastern margin contains paleo subduction/accretion imprints. The crustal structure below this region is seismically imaged using DSS data. Major faults found to be bounded beneath Cuddapah Basin which contains thick sediments. Thick $(20 \mathrm{~km})$ mafic magma underplating is found below the entire study region (Chandrakala et al., 2015). An interesting scientific study has been carried out in western India, Koyna dam that led to reservoir trigger earthquakes. Drilling into depths of the reservoir and the use of seismometers have been 
made to carry out the research (Gupta et al., 2015). Seismic source characteristics in Kachchh and Saurashtra regions of Western India has been studied by b-value and fractal dimension mapping of aftershock sequences. In shallow offshore of KrishnaGodavari basin, India, post-stack seismic inversion and attribute analysis have been done as a part of a research. Porosity is mapped from the transformation of acoustic impedance (Das et al., 2017). Among the factors leading to an earthquake, fluids play a prominent role in the genesis of earthquakes, particularly in intraplate settings. It has been studied in the Kachchh region, northwestern India. Recent research in Himalaya does include a study in Eastern Himalayan Syntaxis done by teleseismic P-wave tomography.

\section{Northeast India}

Seismic tomography using local and regional earthquake data in the northeast region was used to obtain 3D Seismic velocity structures below different tectonic blocks within the region. Figure 1 is a schematic model of the shape of the Indian plate in the upper mantle. The model shows that the high velocity Indian lithosphere is broken/disconnected below the Indo Burma Ranges. The broken off/ disconnected portion is present down to a depth of $\sim 600 \mathrm{~km}$ below Indo Burma Ranges. There could be a lot of lateral displacement between these two parts.

In another study, a 3-D teleseismic P-wave tomography of the Eastern Himalayan Syntaxis has been developed.On the eastern margin of the Himalayan orogenic belt, the rapid uplift of the Namche Barwa metamorphic terrane and significant bending of the Yarlung Zangbo suture zone occur. The formation mechanism and dynamics of the Eastern Himalaya Syntaxis (EHS) is still debated. To better understand the deep structures beneath the EHS, 35 broadband seismic stations around the Namche Barwa Mountain were deployed. The data were integrated with existing datasets for a 3-D teleseismic $\mathrm{P}$-wave tomography. The results demonstrate complex deep structures and significantly contrasting Indian subduction styles in the eastern Himalaya. In the western region of the EHS, the Indian slab flatly subducts under southern Tibet and might extend to the Bangong-Nujiang Suture.

In contrast, a (north) eastward steep subduction occurred in the eastern region of EHS. The contrasting

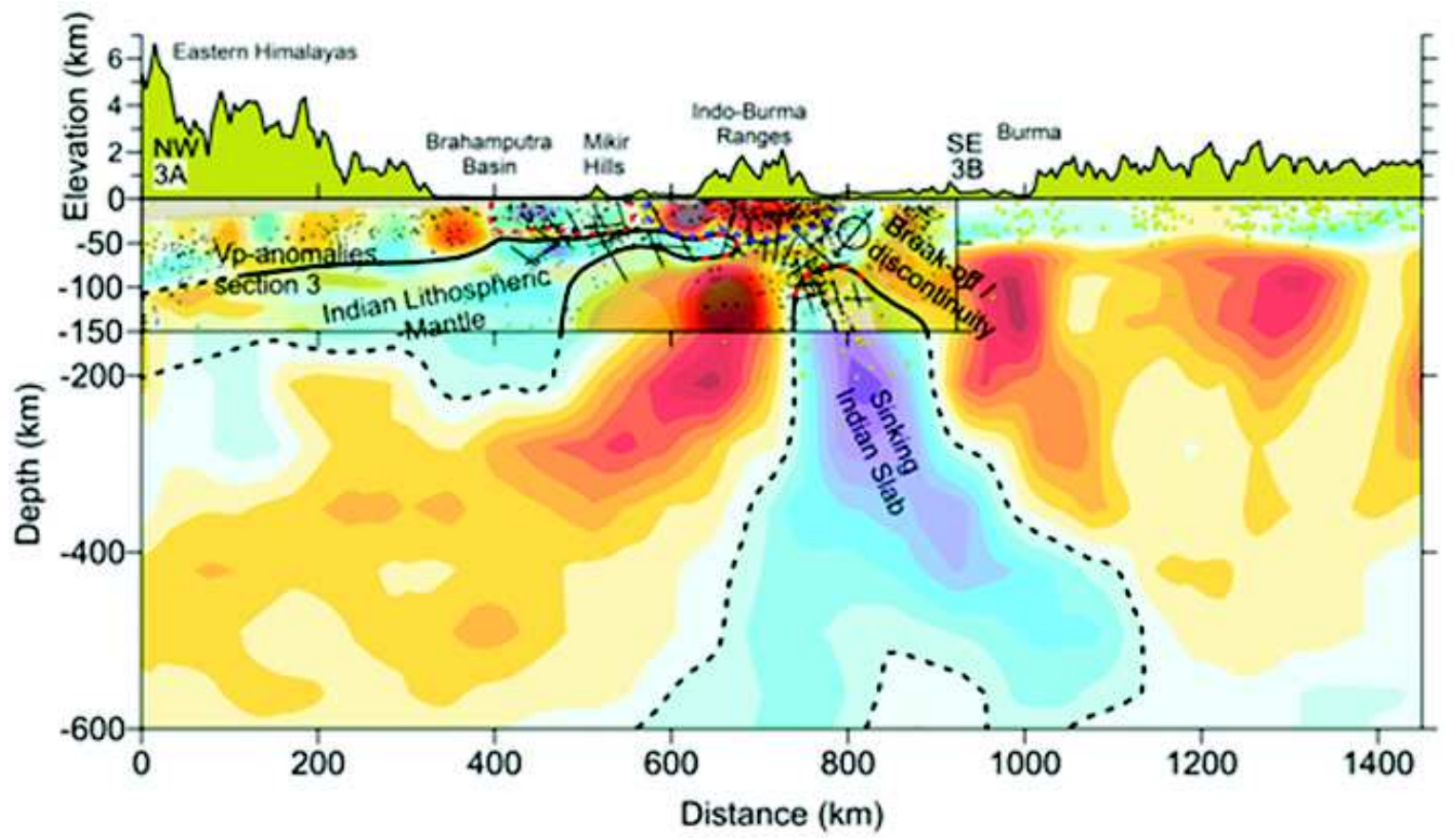

Fig. 1: Cartoon showing the Indian lithosphere along the section presented in Figure 1 that depicts steeply dipping lithosphere below the Indo Burma Ranges, gently dipping below the Eastern Himalayas and buckled up across the NE India region. The black dots indicate projections of the events located within $50 \mathrm{~km}$ on either side of the selected profile (3A and 3B). The yellow dots indicate the distribution of seismicity (ISC data) (After Raoof et al., 2017) 
subduction styles result in tearing and fragmentation of the Indian lithosphere between the flat and steep subducting slabs beneath the EHS. Consequently, the hot asthenospheric mantle may rise through the slab window, which might further lead to the rapid uplift of Namche Barwa and the formation of EHS.

\section{Western India}

A study on Kachchh Seismic Zone, Western India, through Microtremor analysis carried out over diverse geological formations and liquefaction sites in the Kachch seismic zone of western India, which is host to the deadliest intraplate earthquake ( $\mathrm{Mw}$ 7.7). Records from Microtremors at 36 locations with single stations and seven sites with array measurements were made using triangular arrays with sensors kept at 3090 $\mathrm{m}$ radii. The Rayleigh wave velocities, estimated from the array data using a high resolution frequency wave number (f-k) analysis, and the 1D shear wave velocity structure are determined by inversion. A good correlation between surface geology, resonant frequency, and amplitude of the horizontal to vertical spectral ratio (HVSR) curve and shear wave velocity was found. The ground vulnerability index (Kg) values in the liquefied areas were found to be higher than those in the adjacent areas devoid of liquefaction. Further, results show different average fundamental frequencies for the Quaternary, Tertiary, Cretaceous, Jurassic, the Deccan trap formations. The inverted S wave velocity varies from 190 to $1350 \mathrm{~m} / \mathrm{s}$ down to a depth of $200 \mathrm{~m}$ for the Quaternary, 220 to $680 \mathrm{~m} / \mathrm{s}$ down to $100 \mathrm{~m}$ for Tertiary, 236 to $1160 \mathrm{~m} / \mathrm{s}$ for Cretaceous, 670 to $1780 \mathrm{~m} / \mathrm{s}$ for Jurassic, and 260 to $2440 \mathrm{~m} / \mathrm{s}$ for the Deccan trap sites.

Another study on the crustal thickness beneath northwestern Deccan volcanic provinces was done. It presents results of crustal thickness and average crustal $\mathrm{Vp} / \mathrm{Vs}$. ratios beneath this plume affected region using common conversion point imaging and $\mathrm{H} \mathrm{k}$ stacking analysis of 6893 receiver functions using data from a network comprising 58 broadband seismic stations situated on diverse tectonic terrains. The result obtained has variations in crustal thickness, with the Moho depths varying from 28 to $43 \mathrm{~km}$ in the Kachchh rift, 28 to $38 \mathrm{~km}$ in the Cambay rift, $39.5-41.5 \mathrm{~km}$ in the north and eastern parts of the Cambay rift, and 29 to $39 \mathrm{~km}$ in the Saurashtra region and South Gujarat. High crustal Vp/Vs. ratios beneath the
Kachchh rift (1.8 to 2.05), coastal areas of Saurashtra (1.75 to 2.06), and North Gujarat (1.81 to 1.85) indicate a dominance of a mafic/ultramafic crust. High regional heat flow, high electrical conductivity, large intracrustal $\mathrm{S}$ wave velocity reduction, and high average crustal Poisson's ratios are consistent with partial melt related to the process of magmatic underplating in the lower crust.

Earthquakes triggered by filling of artificial water reservoirs have been reported at about 100 sites worldwide during the past seven decades (Gupta 2002, 2011). The occurrence of reservoir-triggered seismicity (RTS) has been associated with several potential factors including the rate of loading, the highest water level reached and the duration of retention of high water levels (Kaiser 1953; Gupta et al., 1972a, b). The Koyna region, located in the $\sim 65$ Ma old Deccan Traps of western India (Fig. 1), is a classical site of RTS. Two core boreholes drilled to depths of 1,522 and 1,196 m have penetrated the Deccan Traps and sampled the granitic basement in the region for the first time. Studies on cores provide new and direct information regarding the thickness of the Deccan Traps, the absence of intra-trappean sediments and the nature of the underlying basement rocks (Fig.4). Seismometers have been deployed in the granitic basement inside two boreholes and are planned in another set of six boreholes to obtain accurate hypocentral locations and constrain the disposition of fault zones.

Fluids play a significant role in the generation of earthquakes in intraplate and interplate settings. The Kachchh rift basin of northwestern India is host to large, deadly intraplate earthquakes like those in 1819 (Mw7.8) and 2001 (Mw7.7). The study provides evidence for the presence of fluids in the seismically active intraplate region of northwest India and demonstrates that the dynamics of mantle fluids controlled by geological faults could lead to significant and moderate sized earthquakes. Combined interpretation of the $2 \mathrm{D}$ geoelectric model and seismic tomography results of the eastern Kachchh suggest the presence of a fluid reservoir at depths of 35-40 $\mathrm{km}$. The near vertical north dipping mantle reaching SWF and the south-dipping NWF seem to serve as feeders for the fluid flow from the reservoir to the epicentral depths 


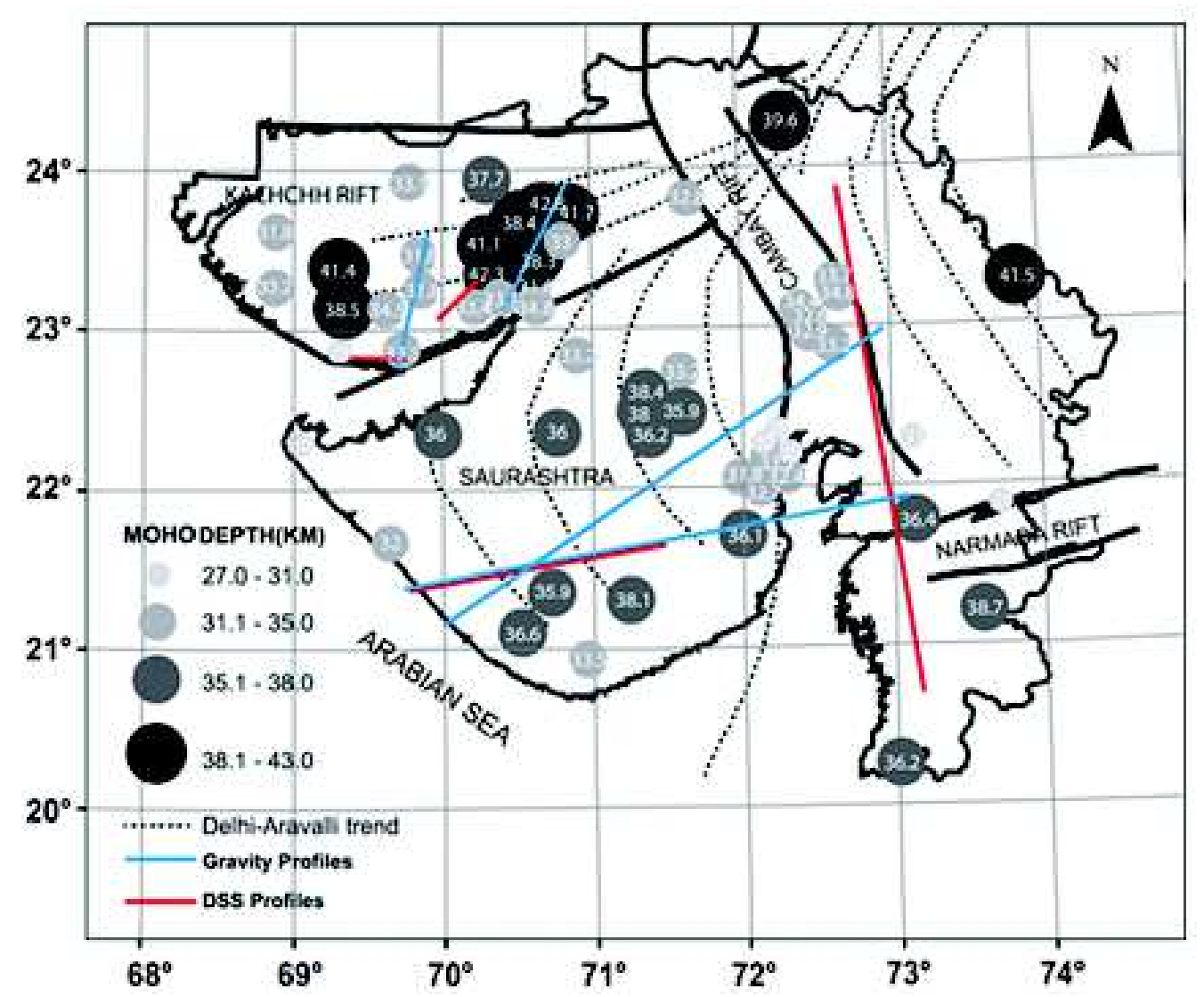

Fig. 2: (Crustal thickness variations in the northwestern Deccan Volcanic Province obtained by $\mathbf{H}$ stacking analysis of receiver functions. Gravity and DSS profiles whose results are used for comparison are also shown) (After Rao et al., 2015)

\section{South-East India}

Like other corners of the country, the South-eastern part is also well explored from the perspective of the seismic study. An approach has been made to understand the evolutionary nature of the area encompassing Cuddapah basin, Nellore Schist Belt and the Ongole domain of Eastern Ghats Belt (south India), which contains Paleo-Neoproterozoic imprints of thick sedimentation, intense magmatism, subduction/ accretion and possible collision between eastern Dharwar craton and east Antarctica. An attempt has been made here to decipher the deep crustal structure and tectonics of this region, by reprocessing Deep Seismic Sounding data acquired earlier through the modeling of first arrival refraction and wide angle reflection travel times. The derived crustal seismic velocity structure reveals that the intracratonic Proterozoic Cuddapah basin containing only $4 \mathrm{~km}$ thick sediment is bounded by two major faults. The
Moho reaching fault detected on its eastern boundary demarcates the Cuddapah basin from the Nellore Schist Belt.The entire stretch of the studied region is underplated by unprecedently thick $(\sim 20 \mathrm{~km})$ high velocity $(7.0-7.4 \mathrm{~km} / \mathrm{s})$ magma layer above the Moho, indicating strong crust-mantle thermal perturbation and massive subcrustal erosion. Further, an expression of a deep-seated mantle thermal anomaly has also been found below the Parnapalle region of the SW Cuddapah basin beneath which deeper crustal layers have exhumed.

Another study at shallow offshore of KrishnaGodavari basin, India, post-stack seismic inversion, and attribute analysis such as amplitude envelope, instantaneous phase and cosine of instantaneous phase of 2D post-stack seismic data facilitates structural and stratigraphic interpretation of shallow marine offshore.Two seismic sections namely, $\mathrm{X}$ and $\mathrm{Y}$ Oriented N-S passing through wells W-1 andW-2 


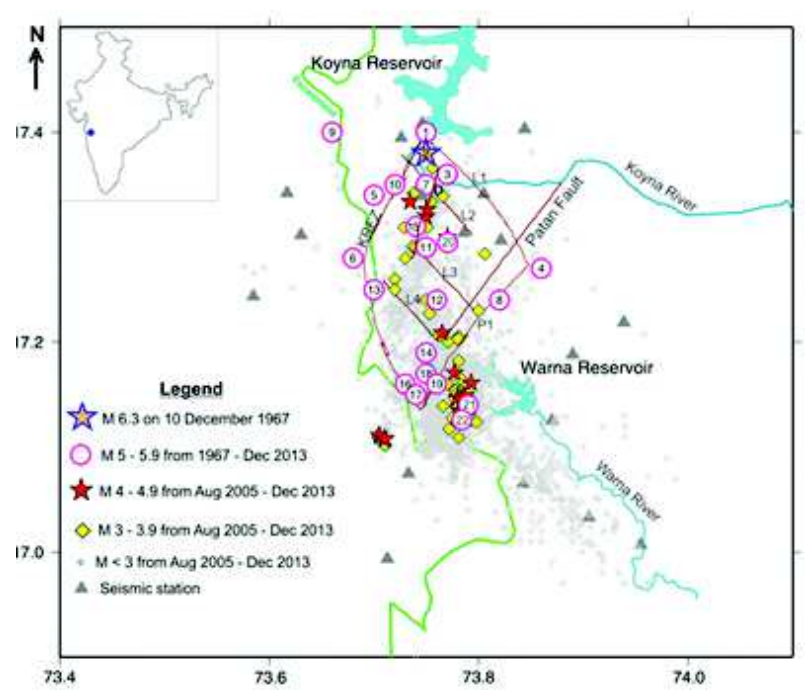

Fig. 3: (Seismic stations and earthquakes in Koyna-Warna region. KRFZ Koyna River fault zone, D Donechiwada fault, and P1 fault parallel to Patan fault, L1, L2, L3, and L4 NW-SE trending fractures (fault geometry by Talwani 1997b). Inset Koyna on India's map) (After Gupta et al., 2015)

respectively are considered for seismic attribute analysis and porosity prediction (Fig. 5). Four seismic zones have been identified. These zones differ in amplitude, frequency and continuity of the reflectors. Channel sands of the Cretaceous age of

\section{References}

Chandrakala K, Pandey O P, Prasad A S S S R S and Sain K (2015) Seismic imaging across the Eastern Ghats Belt-Cuddapah Basin collisional zone, southern Indian Shield and possible geodynamic implications Precambrian Research 271 5664

Das B, Chatterjee R, Singha D K and Kumar R (2017) Post-stack seismic inversion and attribute analysis in shallow offshore of Krishna-Godavari basin, India. Journal of the Geological Society of India $9032-40$

Gupta H K, Rao N P, Roy S, Arora K, Tiwari V M, Patro P K, Satyanarayana H V S, Shashidhar D, Mallika K, Akkiraju V V and Goswami D (2015) Investigations related to deep scientific drilling to study reservoir-triggered earthquakes at Koyna India International Journal of earth sciences 104 1511-1522

Kumar R, Das B, Chatterjee R and Sain K (2016) A methodology of porosity estimation from inversion of post-stack seismic

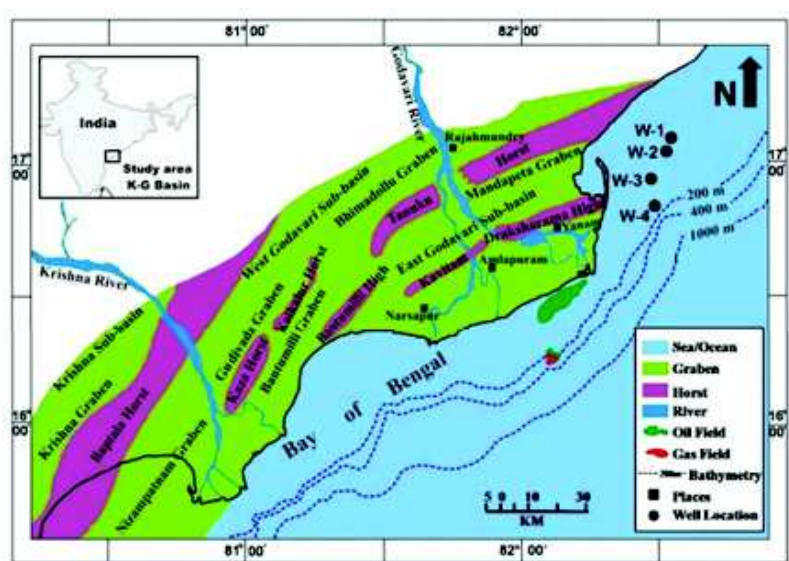

Fig. 4: Illustrate the tectonic map of Krishna-Godavari basin with well locations under the study area (after Das et al., 2017)

Raghavapuram shale are defined in the well log, seismic section and its acoustic impedance section. Major stratigraphic horizons along with faults extending to the basement are marked with the help of attribute analysis. Porosity is mapped from the transformation of acoustic impedance. The shales/ unconsolidated sediments measure a high porosity with low impedance and the more porous sands are in an intermediate range.

data Journal of natural Gas science and engineering 28 356-364

Pavan Kumar G, Mahesh P, Nagar M, Mahender E, Kumar V, Mohan K and Ravi Kumar M (2017) Role of deep crustal fluids in the genesis of intraplate earthquakes in the Kachchh region northwestern India Geophysical Research Letters 44 4054-4063

Peng M, Jiang M, Li Z H, Xu Z, Zhu L, Chan W, Chen Y, Wang Y, Yu C, Lei J and Zhang L (2016) Complex Indian subduction style with slab fragmentation beneath the Eastern Himalayan Syntaxis revealed by teleseismic Pwave tomography Tectonophysics 667 77-86

Qin Y and Singh S C (2015) Seismic evidence of a two-layer lithospheric deformation in the Indian Ocean Nature communications 6 82-98

Rao K M, Kumar M R and Rastogi B K (2015) Crust beneath the northwestern Deccan Volcanic Province India: Evidence for uplift and magmatic underplating Journal of 
Geophysical Research: Solid Earth 120 3385-3405

Raoof J, Mukhopadhyay S, Koulakov I and Kayal J R(2017) 3 D seismic tomography of the lithosphere and its geodynamic implications beneath the northeast India region Tectonics 36 962-980

Singh A P, Roy I G, Kumar S and Kayal J R(2015) Seismic source characteristics in Kachchh and Saurashtra regions of
Western India: b-value and fractal dimension mapping of aftershock sequences Natural Hazards 77 33-49

Singh A P, Shukla A, Kumar M R and Thakkar M G (2017) Characterizing surface geology liquefaction potential, and maximum intensity in the Kachchh seismic zone Western India, through microtremor analysis Bulletin of the Seismological Society of America 107 1277-1292. 